\title{
Development of e-learning media with class room online on device installation materials LAN for student SMK
}

\author{
Kamirin ${ }^{1}$, Olgi Gerieska ${ }^{2}$, Kasman Rukun ${ }^{3}$ Asrul Huda ${ }^{4}$ \\ ${ }^{1234}$ Universitas Negeri Padang, Padang - Indonesia, (kamirin818@gmail.com)
}

\begin{abstract}
Information and computer technology has developed along with the globalization, where a learning system must integrate with the use of computers and the Internet. The purpose of this research is on the LAN device installation and to know the validity and practicalities of the media. This is according to Van Den Akker's consisting of: requirements analysis, design, evaluation and revision. This research resulted from the media in the form of E-Learning with Classroom Online that is validated by a validate with criteria very well $94.28 \%$. A Testing for practicalities is done with 20 . The result of the testing for practicalities is stated that the e-learning Classroom Online is good categorized with an average score of $83 \%$ in terms of the interest of the students, the process of increasing its use, liveliness, time and student evaluation. E-learning in the Classroom Online as one of the alternative media learning materials on the installation of the device for the LAN in the vocational school.
\end{abstract}

Keywords: media, e-learning class room online.

\section{Introduction}

Information and Computer Technology have evolved along with globalization, where learning systems must integrate with the use of computers and the Internet. Computer technology is perceived the need and importance for improvement and improvement of learning quality.

Based on the experience of the writer during the Field Training Practice (PLK) at SMK N 8 Padang in class XI Department of Computer and Network Engineering on 25 August to 29 October 2014, the researcher assessed that during the learning process, teachers are still implementing conventionally by utilizing learning hours formal in the absence of independent learning outside formal lessons with the use of internet access. Other problems seen are the existence of Information Technology that has supported the learning process, the lack of utilization of facilities that have been owned schools, especially information technology facilities that have been connected to the internet and lack of availability of learning media.Whereas in this school there are already adequate facilities to support teaching and learning process such as a computer connected to the Internet connection.

With such problems, the need for an innovation in the learning process, the innovation in question is the learning process using the Internet or commonly called E-Learning. E-Learning is an educational process that utilizes information and communication technology to bridge learning and learning activities. One of the most popular E-Learning for learning is Claroline. Claroline is an open 
source licensed LCMS platform, claroline enables a teacher to build an effective online classroom, managing learning and collaborative activities through the Internet (Prawiradilaga 2013: 319).

The objective of this research is to produce E-Learning learning media with Class Room Online which is valid and practical and know the validity and practicality of E-Learning learning media with Class Room Online On Material Installation of LAN Device for vocational students.

\section{Method}

In accordance with the problems studied, then this type of research is research development (Research and Development / RD). Research development approach (Research Development) is a research approach proposed by Van Den Akker. The research process starts from the activity that is: need's analysis, design, evaluation, and revision (Akker, 1999: 7).

Research procedure

1. Need's analysis is the first step in a development study. At this stage, the researcher analyzes the subject matter to be developed. Furthermore, to analyze the characteristics of students who include background ability, and analyze the ability of teachers in overcoming the limitations of media in learning activity's installation of LAN devices in schools.

2. Design stage, At this stage E-Learning learning media that developed adapted to the subject's Installation of LAN device's class XI Vocational Secondary School (SMK).

3. Validation / Revision, At this stage media that has been made will be evaluated. By testing the experts and students in small groups.

4. Test phase, At this stage, the resulting product is implemented in the learning activities. Trial conducted is a limited trial, namely on one class XI TKJ SMK. At this stage, the researcher acts as teacher and teacher acts as an observer.

Then done with the implementation by step product testing and practice test. The steps taken can be seen in Figure 1:

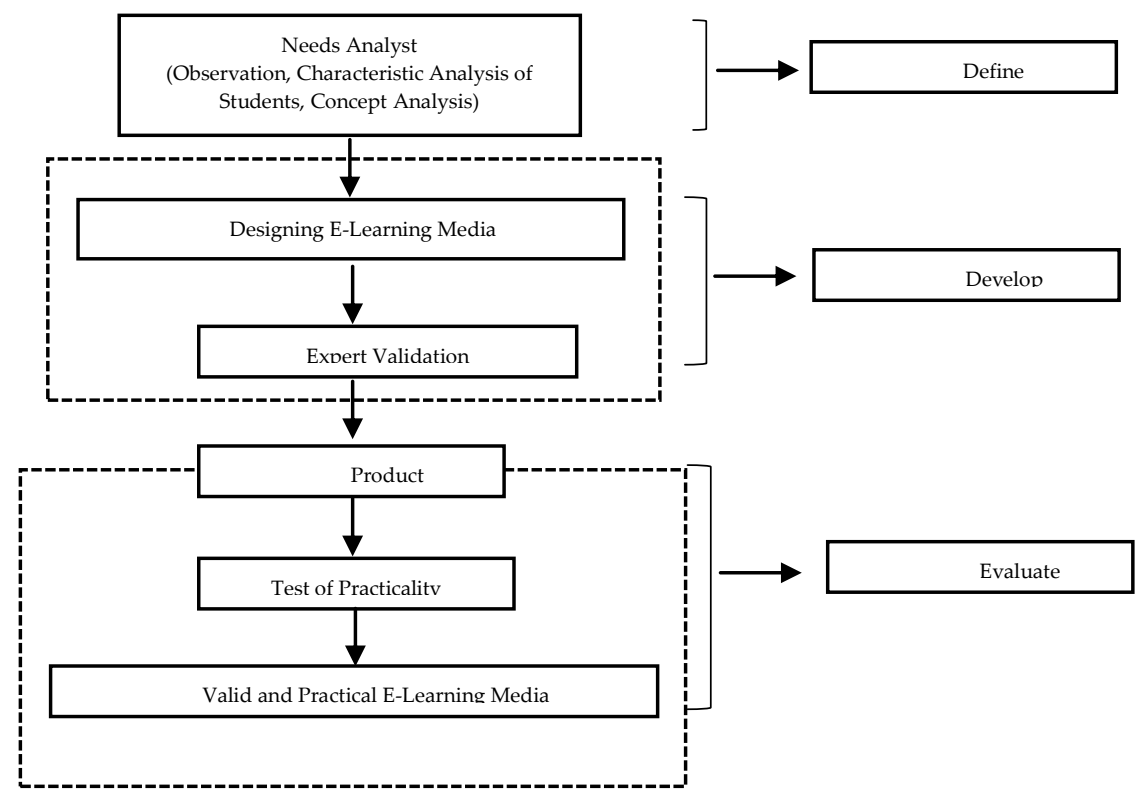

Figure 1: Draft of Learning Media Creation 
Development of E-Learning with Class Romm Online for the material Installation of this LAN Tool is class XI students TKJ SMK N 8 Padang, amounting to 20 people.

\section{Data analysis technique}

1. Technique of validity analysis

The results from the validationquestionnaire to the development of web-based learning media will get validate results on all aspects assessed. Validate media is determined by taking the conclusion of the response given by the validate to the statement displayed in the questionnaire.

E-Learning media analysis with Classroom Online for LAN Device Installation materials, done by experts by providing score of answers with criteria in accordance with instructional materials development guide based on ICT Ministry of National Education, (2010: 17) as follows:

Table1. criteria of validity

\begin{tabular}{ccc}
\hline No & Level of Achievement & Category \\
\hline $\mathbf{1}$ & $<50 \%$ & Less \\
$\mathbf{2}$ & $51 \%-70 \%$ & Enough \\
$\mathbf{3}$ & $71 \%-9 \%$ & Good \\
$\mathbf{4}$ & $91 \%-100 \%$ & Very good
\end{tabular}

2. Technical of Practical Analysis

Practical analysis is done to teachers and learners by providing questionnaires to web-based learning media.

Analysis of student responses to E-Learning learning with Class Room Online. The data tested by E-Learning media practitioners with Class Room Online for LAN Device Installation materials was analyzed by percentage (\%), using the following formula:

$$
\text { Practical Value }=\frac{\text { Number of all scores }}{\text { Max Score }} \times 100 \%
$$

After the percentage of practicality value obtained, the grouping according to the criteria proposed by Purwanto (2009: 102-103) below:

\begin{tabular}{ccc}
\hline No & Level of Achievement & Category \\
\hline $\mathbf{1}$ & $90 \%-100 \%$ & Very good \\
$\mathbf{2}$ & $80 \%-89 \%$ & Good \\
$\mathbf{3}$ & $65 \%-79 \%$ & Good enough \\
$\mathbf{4}$ & $55 \%-64 \%$ & Bad \\
$\mathbf{5}$ & $0 \%-54 \%$ & Verry Bad \\
\hline
\end{tabular}




\section{Results And Discussion}

The research procedure used is development research procedure according to Van Den Akker. With the research process starting from the stage of need's analysis, design, evaluation and revision (Akker, 1999: 7). However, in this study, the development stage of learning media is only up to the stage of small-scale product testing and product revision. Need's analysis is intended to find and determine the basic problems in the learning process, especially on LAN Device Installation materials, so that later need's to be developed a learning media to be a solution in solving existing problems.

The research procedure used is IDI research procedure. IDI development model (Instructional Development Institute). IDI development process includes three stages of define, develop and evaluate. The three stages are linked with feedback to make revisions (Syukur, 2008).Need analysis is intended to find and determine the basic problem in the learning process especially on the material of LAN Device Installation, so that later it is necessary to develop a learning media for a solution in solving existing problems. After the analysis is done proceed with developing the media in accordance with the needs that are validated by experts.

\section{Validity of E-Learning Media with Class Room Online}

Based on the validity test of E-Learning media with Class Room Online is done by 2 lecturers from the department of PTIK UBH using a questionnaireof validity test. It was concluded that the ELearning medium with Class Room Online created is very valid and good, it can be used as a learning media with little revision.

Components Instrument assessment of teaching materials refers to four parts:

a. Substance Material: truth, depth, presentness, and legibility

b. Learning Design: title, SK, KD, indicators, materials, sample questions, exercises, authors, and references

c. Display (visual communication): navigation, typography, media, color, animation and simulation

d. Software Utilization: interactive, software support, authenticity

When conducting a validity test with validate I, Dr.Eril Syahmaidi, M.Pd on e-learning media with online class room on April 27, 2015 then obtained some criticism and suggestion, the first in substance category of material which needs to be added a reference book (Score 7), both on the visual communication display of the sound must be clear (Score 10), the three instructional designs need to be added powerpoint in each material (Score 28), and lastly on the software utilization it is necessary to add the self-designed video (Score 8) score only 51 with percentage $72.85 \%$ (Good).

After getting criticism and suggestion from validate I researcher do product improvement, on April 30, 2015 the product has been repaired according to criticism and suggestion done validation II. The result of validation II is: material substance is valid (Score 11), Visual communication display is valid (Score 18), Learning design is valid (Score 26) and software utilization also valid (Score 11). In other words, E-Learning media with Class Room Online can be continued for research with 66 and $94.28 \%$ (Very Good).

Furthermore, E-Learning media with Class Room Online also valid test with validate II that is father of Ashabul Khairi, M.Kom obtained critic and suggestion as follows: first on substance of material need to be improved reference source (Score 11), secondly in view visual communication added animation (Score 13), the third on the learning design has been obtained valid criteria (Score 27 ), and the last category of software utilization are also valid (Score 10) so the total score is only 60 with $85.71 \%$ percentage (good). From the above description there are two categories that have not been valid so that the researcher tried to make improvements in order to obtain valid category from 
E-Learning media with Class Room Online developed. In the second valid test with validate II the categories are not valid yet again checked in detail by the validate and validate concluded that: first in the category of material substance is valid (Score 12), both visual communication display is valid (Score 17), the three instructional designs are also valid (Score 27), and the last valid software utilization (Score 10). So get the media information worthy of use as a medium of learning in the column of criticism and suggestions with a score of 66 and a percentage of $94.28 \%$ (Very good).

\section{Practical Media E-Learning with Class Room Online}

The test result of E-Learning media questionnaire with Class Room Online using SPPS is practical. to see the practical and impractical of each item, seen from the correlation coefficient value in the column Corrected item-Total Correlation. Compare this value with the correlation coefficient in the table $\mathrm{r}$ table, ie: with $\mathrm{df}=\mathrm{N}-2=19-2=17$ and $\alpha=5 \% \mathrm{r}$ table $\mathrm{r}=0.370$ obtained using SPSS.

Hypothesis for practicality is if $\mathrm{r}$ arithmetic $>\mathrm{r}$ table and positive value then it is declared practicalThe data of students' practicality test results can be seen in Table 1.

\begin{tabular}{clrc}
\hline No & Practical Variables & Practical Value & Criteria \\
$\mathbf{1}$ & Student Interest & $83 \%$ & Good \\
$\mathbf{2}$ & Process Usage & $83 \%$ & Good \\
$\mathbf{3}$ & Increased Student Activity & $85 \%$ & Good \\
$\mathbf{4}$ & Availability of Time & $82 \%$ & Good \\
$\mathbf{5}$ & Evaluation & $84 \%$ & Good \\
\hline
\end{tabular}

Tabel 1 : Student Practical Test Results.

From the above table the value of practicality to student interest of $83 \%$., $83 \%$ utilization process, $85 \%$ student activeness increase, availability time of $82 \%$ and evaluation of $84 \%$. From these results can be averaged at $83 \%$. So it can be said to be practical.

The results of this practice are described in the following graph.

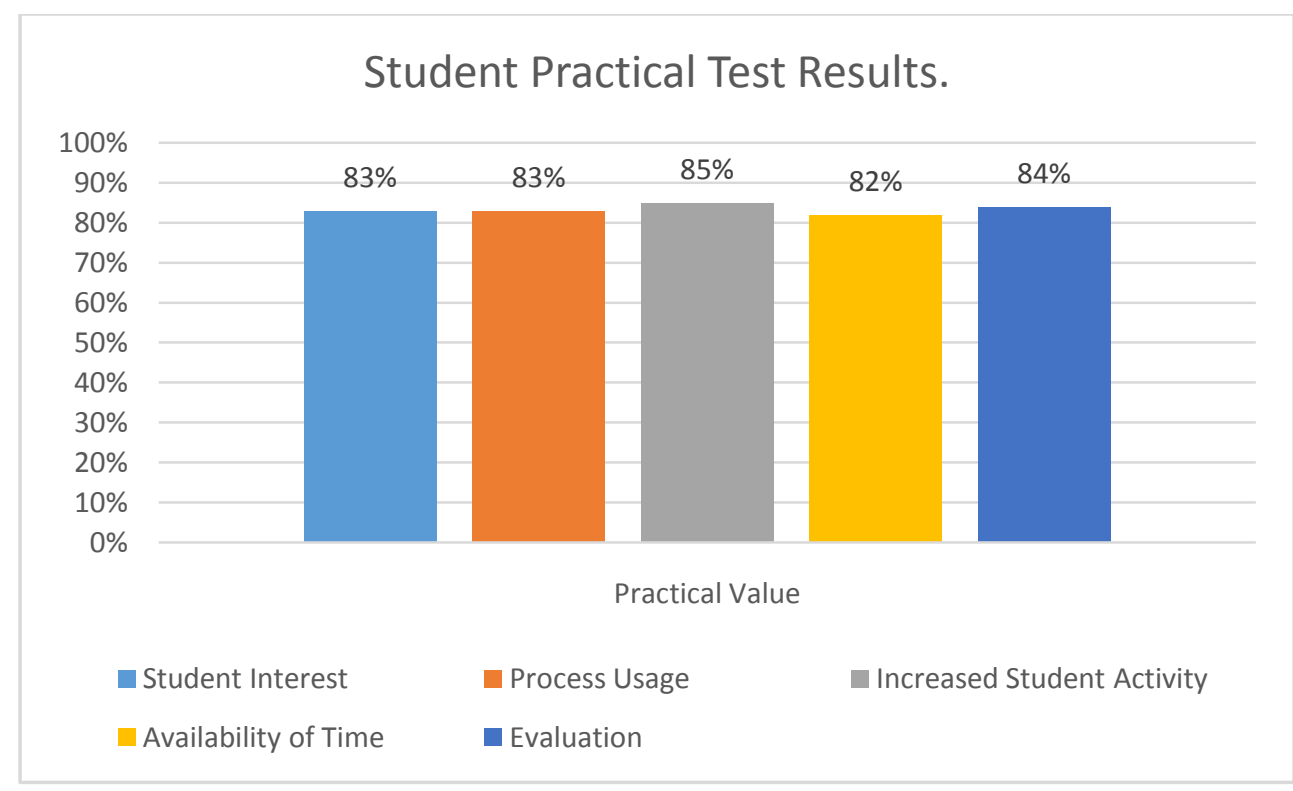

Graph 1. Student Practical Test Results. 
The presence of E-Learning media with Class Room Online has answered the problem of the absence of E-Learning media with Class Room Online is valid and practical. Thus, issues that are restricted to the problem boundary have been answered. E-Learning Media with Class Room Online can be used as an alternative to learning outside the formal learning hours which is limited space and time so that it can be used by students and teachers in self-learning either at school or at home to support process learning.

Although basically validation and practice have been done and get a goodcategories, but in ELearning media with Class Room Online that researchers developed still has its weaknesses, among others:

1. Absence of the absentee taking system.

2. Not yet support for photos and videos in the media.

3. In terms of control and management, there is no system to record or scan the faces of learners who use the media, so it can be signed in using the e-learning account is not the studentconcerned but it could be other people.

The first weakness can be solved by taking the abscess through the chat feature by giving the time span in the absence, For the second problem is solved by providing links to sites that have been selected to store videos or photos relating to learning, while for the third problem about the control the system management still cannot be overcome in this research and the researcher hopes to will do further research about E-Learning media with Class Room Online this can develop things that cannot solve researcher in this research. However, the things that become obstacles above can still be tolerated by the validate because this is a new developer that researchers do in presenting alternative learning media that can support the formal learning process.

\section{Conclusions}

Based on the results of research that has been obtained, it can be concluded that the E-Learning media with to Class Room Online on the material installation off LAN Devices for Students SMK worthy to be used as a medium of learning outside the formal hours. Because the E-Learning media with to Classroom Online developed the overall validity score of $94.28 \%$ with very good criteria from two validators and $83 \%$ practicality score with good criteria by students.

\section{Acknowledgments}

1. Prof. Mr. Dr. Kasman Rukun, M.Pd as the Head of Master Program of PTK UNP as well as the always wise counselor provides guidance, advice, and time during doing research and writing of this Journal.

2. Mr. Asrul Huda, M.Kom as the Second Counselor who has provided assistance, guidance and direction in preparing this journal

3. Mr. Dr. Eril Syahmaidi, M.Pd as Media E-Learning Validate With Class Room Online

4. Mr. Ashabul Khairi, M. Kom as Media Validator E-Learning With Class Room Online.

5. Mrs. Santi, M.Kom as the Teacher of Local Area Network Installation Lesson at SMK N 8 Padang that has given directions, advice, and time to the writer to do the research.

\section{References}

Akker, J.V. (1999). Design Approaches and Tool in Education and Training.Dordrecht:Kluwer Academic Publishers. 
Arsyad, Azhar. (2013). Media Pengajaran. Jakarta: PT RajaGrafindo Persada.

Asyhar, Rayandra. (2012). Kreatif Mengembangkan Media Pembelajaran. Jakarta: Referensi Jakarta.

Clark, Mayer. (2008). E-Learning and the science of instruction proven guidelines for consumers and designers of multimedia learning. Pfeiffer. San Pransisco.

Kementerian Pendidikan Nasional. (2010). Panduan Pengembangan Bahan Ajar Berbasis TIK. Jakarta. Direktur Pembinaan SMA.

Prawiradilaga, Dewi Salma., dkk. (2013). Mozaik Teknologi Pendidikan E-Learning.Jakarta: Prenada Media.

Purwanto, Ngalim. (2009). Prinsip-prinsip dan teknik evaluasi pengajaran. Bandung: Remaja Rosda Karya.

Rusman. (2013). Belajar dan Pembelajaran Berbasis Komputer Mengembangkan Profesionalisme Guru Abad 21. Bandung: Alfabeta.

Sugiyono. (2014). Metode Penelitian Kuantitatif, Kualitatif dan RED. Bandung: Alfabeta.

Syukur, F. (2008). Teknologi Pendidikan. Semarang : Rasail Media Group. 